\title{
Fundibacter jadensis gen. nov., sp. nov., a new slightly halophilic bacterium, isolated from intertidal sediment
}

\author{
Alke Bruns and Luise Berthe-Corti
}

\author{
Author for correspondence: Luise Berthe-Corti. Tel: +49441798 3290. Fax: +49 4417983250. \\ e-mail: Be-corti@hrz2.uni-oldenburg.de
}

Fachbereich Biologie, C.v.O. Universität Oldenburg, PO Box 2503 D-26111 Oldenburg, Germany

\begin{abstract}
A moderately halophilic hydrocarbon-degrading bacterium was isolated from continuous cultures containing a suspension of intertidal sediment from the German North Sea coast with hexadecane as the sole carbon source. On the basis of phenotypic characteristics, fatty acid analysis and 165 rDNA sequence analysis, it was considered to be a new species belonging to a new genus. It is a Gram-negative, aerobic, rod-shaped bacterium, whose cell size varies. It grows at concentrations of $0.5-15 \%(w / v) ~ N a C l$ and utilizes a restricted spectrum of carbon sources. The G+C content of the DNA is $63.6 \mathrm{~mol} \%$. Comparative 165 rDNA studies show a clear affiliation of this bacterium to the gamma subclass of the class Proteobacteria. Comparison of phylogenetic data indicate that it is most closely related to Marinobacter hydrocarbonoclasticus (88.9\% similarity in 165 rRNA gene sequence). Since it is impossible to find a sufficiently closely related species, we propose the name Fundibacter jadensis gen. nov., sp. nov. for the bacteria. The type strain is $\mathrm{Tg}^{\top}$ (=DSM 12178').
\end{abstract}

Keywords: intertidal sediment, gamma-Proteobacteria, hydrocarbon degradation

\section{INTRODUCTION}

Studies were made to characterize the substrateutilization pattern of the alkane-degrading bacterial population indigenous in the intertidal sediment of the Jadebusen Bay (German North Sea coast). For this, continuous-flow cultures containing mud-flat sediment and hexadecane as the sole carbon source were performed (Berthe-Corti et al., 1997). These cultures led to the isolation of numerous hydrocarbon-degrading strains. A Gram-negative bacterium, named strain $\mathrm{T} 9^{\mathrm{T}}$, able to grow both anaerobically and at oxygen saturation, showed a restricted spectrum of carbon sources that were metabolized, but was able to degrade various long-chain alkanes. The bacterium is characterized by a variable cell morphology and belongs to the gamma subclass of the class Proteobacteria. It was not possible to assign it to a known genus.

In this paper, we present the results of the phenotypic

Abbreviations: $\mathrm{PHB}$, poly- $\beta$-hydroxybutyrate; SM, synthetic medium; SWM, seawater medium.

The EMBL accession number for the 165 rDNA sequence from $F$. jadensis reported in this paper is A 001150. and biochemical examinations of the strain. The phylogenetic relationships to other bacteria were analysed by $16 \mathrm{~S}$ rDNA sequence analysis and the application of specific rRNA-directed oligonucleotide probes. The data suggest that the organism isolated belongs to a new genus and represents a new species, for which we propose the name Fundibacter jadensis gen. nov. sp. nov., according to the geographic site where the organism was isolated from.

\section{METHODS}

Isolation. Strain $\mathrm{T}^{\mathrm{T}}$ was isolated from an aerobic continuous culture with a suspension containing sediment of the intertidal zone of the German North Sea coast (Jadebusen). The suspension was supplemented with hexadecane as the sole carbon source (Berthe-Corti et al., 1997). For isolation, $10 \mathrm{ml}$ samples from the culture suspension were ultrasonically treated $\left(3 \times 30 \mathrm{~s}, 30 \mathrm{~W}, 4^{\circ} \mathrm{C}\right.$; Branson sonifier), spread over a solid medium (for composition see modified nutrient agar) and incubated at $25^{\circ} \mathrm{C}$ for $1-3$ weeks. From plates containing 30-50 colonies, all colonies were picked and restreaked several times to obtain pure cultures. The isolated cultures were chosen to make detailed studies of their hydrocarbon-degrading activity.

Growth media. General laboratory cultivation was per- 
formed on modified nutrient agar containing $2 \cdot 5 \mathrm{~g}$ Bacto peptone (Difco), $1.5 \mathrm{~g}$ yeast extract, $2.0 \mathrm{ml}$ hexadecane, $15.0 \mathrm{~g}$ agar-agar, $750 \mathrm{ml}$ artificial seawater and $250 \mathrm{ml}$ distilled water. The artificial seawater contained per litre distilled water (Levring, 1946): $23.6 \mathrm{~g} \mathrm{NaCl} ; 0.64 \mathrm{~g}$ $\mathrm{KCl} ; 4.53 \mathrm{~g} \mathrm{MgCl}_{2} .6 \mathrm{H}_{2} \mathrm{O} ; 5.94 \mathrm{~g} \mathrm{MgSO}_{4} .7 \mathrm{H}_{2} \mathrm{O} ; 1.3 \mathrm{~g}$ $\mathrm{CaCl}_{2} \cdot 2 \mathrm{H}_{2} \mathrm{O}$. To avoid precipitation, the $\mathrm{CaCl}_{2} \cdot 2 \mathrm{H}_{2} \mathrm{O}$ was sterilized separately. The $\mathrm{pH}$ of the medium was adjusted with $\mathrm{NaHCO}_{3}$ to $\mathrm{pH} 7.2$ and incubation was carried out at $25^{\circ} \mathrm{C}$. For some phenotypic characterizations, the organism was cultivated in a synthetic medium (SM) (Gauthier et al., 1992) supplemented with $1 \%(\mathrm{w} / \mathrm{v})$ acetate as the sole carbon source or in a seawater medium (SWM) containing (per litre artificial seawater): $0 \cdot 1 \%(\mathrm{w} / \mathrm{v})$ of the carbon sources listed in Table 1; $43 \mathrm{mg} \mathrm{Na} \mathrm{HPO}_{4} .2 \mathrm{H}_{2} \mathrm{O} ; 220 \mathrm{mg}$ $\mathrm{NaNO}_{3} ; 650 \mathrm{mg} \mathrm{NH} / \mathrm{Cl} ; 46 \mathrm{mg} \mathrm{NaHCO} ; 3 \mathrm{ml}$ vitamin solution (Schlegel, 1992) and $1 \mathrm{ml}$ mineral salts solution (medium no. 124; DSMZ catalogue of strains, 1993). Incubation was performed at $25^{\circ} \mathrm{C}$. To obtain biomass for the fatty acid analysis, cells were grown in a liquid medium containing: $4.16 \mathrm{~g} \mathrm{CH} \mathrm{CH}_{2} \mathrm{COONa} ; 3 \mathrm{ml}$ vitamin solution (as above); $1 \mathrm{ml}$ mineral salts solution (as above); $1.46 \mathrm{~g}$ $\mathrm{NaNO}_{3} ; 0.14 \mathrm{~g} \quad \mathrm{Na}_{2} \mathrm{HPO}_{4} ; 750 \mathrm{ml}$ artificial seawater (Levring, 1946) and $250 \mathrm{ml}$ distilled water; $\mathrm{pH} 7 \cdot 2$ (adjusted with $\mathrm{NaOH}$ ). The incubation was performed at $25^{\circ} \mathrm{C}$.

Phenotypic characterization. Cell morphology was determined by examining cultures of different ages by phasecontrast microscopy. Flagella were examined by the staining method according to Drews (1976). Colony morphology was studied using a stereomicroscope. Transmission electron microscopy (transmission electron microscope 109, Zeiss) was carried out with negatively stained cells (Cole \& Popkin, 1981) of $42 \mathrm{~h}$ and $4 \mathrm{~d}$ cultures grown in the liquid medium used for the fatty acid analysis. Catalase and oxidase tests were done as described by Smibert \& Krieg (1994). The Gram reaction was studied with the aminopeptidase test (Merck) and by gram staining (Smibert \& Krieg, 1994). The temperature range for growth was determined by incubating liquid cultures in $\mathrm{SM}$ between 4 and $50^{\circ} \mathrm{C}$. The $\mathrm{pH}$ range was determined in liquid SM with a final $\mathrm{pH}$ between 5.0 and 10.0. Salt tolerance was studied in liquid SM containing $0-30 \%(\mathrm{w} / \mathrm{v}) \mathrm{NaCl}$. Utilization of carbon sources was tested in liquid SM omitting peptone and acetate but supplementing with $0 \cdot 1 \%(\mathrm{w} / \mathrm{v})$ of the various carbon sources including the long-chain or aromatic hydrocarbons tetradecane, hexadecane, eicosane, heneicosane, pristane and phenanthrene (Table 1). Additionally, growth in a seawater medium supplemented with vitamins and trace elements, and with the same carbon sources (Table 1) except eicosane and heneicosane was examined. Growth was estimated after 1 week incubation at $25^{\circ} \mathrm{C}$ from $\mathrm{OD}_{600}$ with a Perkin Elmer 550S UV/VIS spectrometer. Susceptibility to inhibitors was analysed on modified nutrient agar without hexadecane but supplemented with $0.3 \%(\mathrm{w} / \mathrm{v})$ acetate by performing the disk diffusion test with the following antibiotics (Bio-disks; bioMérieux): ampicillin $(10 \mu \mathrm{g})$, cefazolin $(30 \mu \mathrm{g})$, cephalothin $(30 \mu \mathrm{g})$, chloramphenicol $(30 \mu \mathrm{g})$, erythromycin $(15 \mu \mathrm{g})$, gentamicin $(30 \mu \mathrm{g})$, linomycin $(15 \mu \mathrm{g})$, nalidixic acid $(30 \mu \mathrm{g})$, novobiocin $(5 \mu \mathrm{g})$, ofloxacin $(5 \mu \mathrm{g})$, oxacillin $(5 \mu \mathrm{g})$, penicillin $(10 \mu \mathrm{g})$, tetracycline $(30 \mu \mathrm{g})$ and tobramycin $(30 \mu \mathrm{g})$.

For determining denitrification, cells were grown anaerobically in a modified liquid nutrient broth without hexadecane but supplemented with $0.3 \%(\mathrm{w} / \mathrm{v})$ acetate and $0.1 \%$ $(\mathrm{w} / \mathrm{v}) \mathrm{KNO}_{3}$. After one week of incubation, the formation of nitrite was determined by a dot reaction described by Näveke
\& Tepper (1979). Gaseous $\mathrm{N}_{2}$ production was analysed gas chromatographically using a Shimadzu 8A chromatograph equipped with a thermal-conductivity detector. A Chrompack $13 \mathrm{~A}$ column $(80 / 100 \mathrm{mesh}, 2 \mathrm{~m} \times 3 \mathrm{~mm}$; Macherey-Nagel) was used for the $\mathrm{N}_{2}$ analysis and a Porapack QS column $(100 / 120$ mesh, $2 \mathrm{~m} \times 3 \mathrm{~mm}$; Macherey-Nagel) for the $\mathrm{N}_{2} \mathrm{O}$ analysis. Helium was used as

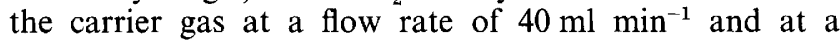
temperature of $50{ }^{\circ} \mathrm{C}$. The injector and detector temperature was $140{ }^{\circ} \mathrm{C}$.

To determine intracellular poly- $\beta$-hydroxybutyrate (PHB), heat-fixed cells were stained with $1 \%(\mathrm{w} / \mathrm{v})$ Nile blue $A$ solution for $10 \mathrm{~min}$ at $55^{\circ} \mathrm{C}$, rinsed with water and then with $8 \%(\mathrm{v} / \mathrm{v})$ acetate in distilled water. Cells containing intracellular PHB showed an orange colour after excitation by light at $436 \mathrm{~nm}$ under an epifluorescence microscope.

Fatty acid analysis. Cells were cultivated in the abovementioned medium for fatty acid analysis, harvested by centrifugation $(30 \mathrm{~min}, 25900 \mathrm{~g}$ ) and washed twice in artificial seawater (Grasshoff, 1983). The extraction of fatty acids was done according to the MIDI system (Sasser, 1990). This system is based on the methylation of fatty acids. The extracted fatty acid methyl esters were separated by chromatography on a fused-silica capillary column [50 $\mathrm{m} \times 0.25 \mathrm{~mm}$ (internal diameter)] with an HP 5980A chromatograph (Hewlett Packard) equipped with a flameionization detector and a HP-3396 integrator (Hewlett Packard), using $\mathrm{H}_{2}$ as the carrier gas at a flow rate of $15 \mathrm{ml}$ $\mathrm{min}^{-1}$ and at temperatures ranging from 150 to $250^{\circ} \mathrm{C}$, ramp rate $4^{\circ} \mathrm{C} \mathrm{m^{-1 }}$. A standard mixture (Matreya) containing defined fatty acids $\left(\mathrm{C}_{11}-\mathrm{C}_{20}\right.$ straight-chain, saturated, unsaturated, hydroxy, cyclopropane, iso and anteiso fatty acids) was used as a reference for comparison.

DNA base composition. The $\mathrm{G}+\mathrm{C}$ content of the DNA of strain $\mathrm{T}^{\mathrm{T}}$ was determined from DNA extracted with the QIAmp Tissue Kit (Qiagen). The procedure recommended by the manufacturer was modified: the enzymes and buffers were used as described in the Large Sample Protocol, but the actual extraction was done by the Tissue Protocol. Before loading the columns, SDS was added to the suspension at a final concentration of $2 \%(\mathrm{w} / \mathrm{v})$ and incubated for $10 \mathrm{~min}$ at $65^{\circ} \mathrm{C}$. To gain a higher DNA purity, an additional washing step with buffer AW1 (Qiagen) was carried out and the solution was extracted twice with chloroform/ isoamylalcohol (24:1) (Hill, 1968). The dialysed DNA (in $0.1 \times$ SSC) was examined using the thermal denaturation method (Mandel \& Marmur, 1968) with a Gilford 2600 spectrophotometer.

165 rDNA sequence determination. This analysis was done by the DSMZ. Genomic DNA was extracted, and PCR amplification of the 16S rRNA genes was performed as described by Rainey et al. (1996). Purified PCR products were sequenced using a PRISM Dye Terminator Cycle Sequencing Ready Reaction Kit (Applied Biosystems) as recommended by the manufacturer. The purified sequence reaction mixtures were electrophoresed using an Applied Biosystems model 373A DNA sequencer. The determined sequence was manually aligned with the alignment editor ae2 (Maidak et al., 1996) and compared with sequences of reference micro-organisms which belong to the gamma subclass of the Proteobacteria (EMBL and RDP databases). Evolutionary distances calculated by the method of Jukes \& Cantor (1969) were used to construct a phylogenetic tree by the neighbour-joining method (Saitou \& Nei, 1987). 


\section{RESULTS}

\section{Morphological and cultural characteristics}

$F$. jadensis strain $\mathrm{T} 9^{\mathrm{T}}$ is a Gram-negative, rod-shaped, non-motile organism. Cells grown in the liquid medium used for fatty acid analysis were $0.8-1.8 \mu \mathrm{m}$ long and $0.3-0.7 \mu \mathrm{m}$ wide. The cell sizes were quite variable (Fig. 1a). Since an infection by other bacteria can be excluded, we have to assume that the variability of the cell size is a feature of this strain. Cells of older cultures (4d) were characterized by peritrichous pili which could be seen by transmission electron microscopy of negatively stained cells (Fig. 1b). No flagella were observed (Fig. 1b, c). Cells divided by binary fission (Fig. 1c).

On modified nutrient agar, the colonies of strain $\mathrm{T} 9^{\mathrm{T}}$ were $0.25-1.25 \mathrm{~mm}$ in diameter, smoothly circular, slightly raised, with regular edges and ivory pigmentation.

\section{Growth properties}

Strain $\mathrm{T} 9^{\mathrm{T}}$ is a slightly halophilic bacterium. It grows in liquid media containing $0.5-15 \%(\mathrm{w} / \mathrm{v}) \mathrm{NaCl}$, with optimal growth at $3 \%(\mathrm{w} / \mathrm{v}) \mathrm{NaCl}$. The $\mathrm{pH}$ tolerance ranged between $\mathrm{pH} 6.0$ and 8.5 , the optimum for growth was $\mathrm{pH} 7 \cdot 0$. The strain was able to grow at temperatures from 10 to $40^{\circ} \mathrm{C}$, with optimal growth at $30^{\circ} \mathrm{C}$.

\section{Physiological characteristics}

Strain $\mathrm{T} 9^{\mathrm{T}}$ showed anaerobic growth with nitrate as an electron acceptor and acetate as a carbon source. It is an organism which anaerobically reduces nitrate to nitrite, but is not able to produce $\mathrm{N}_{2}$. Using a reference colour scale (max. 1 g $\mathrm{NaNO}_{2}^{-} \mathrm{l}^{-1}$ ) in the dot reaction we concluded that almost all of the nitrate supplementation in the medium was reduced to nitrite. However, no production of $\mathrm{N}_{2}$ or $\mathrm{N}_{2} \mathrm{O}$ during growth in the medium supplemented with nitrate was detected by GC.

Tests for aerobic growth on liquid SM (medium without vitamins and mineral salts) supplemented with different carbon sources and ammonium as a nitrogen source, as performed by Gauthier et al. (1992), revealed a very restricted spectrum of growth substrates. In SM, only acetate and pyruvate caused detectable cell growth within an incubation time of $14 \mathrm{~d}$ (Table 1). Growth on the same carbon sources was also tested using SWM (containing vitamins and trace elements). Besides pyruvate and acetate, strain $\mathrm{T} 9^{\mathrm{T}}$ also utilized pristane, tetradecane and hexadecane for growth. Using SWM and omitting vitamins and trace elements, we were able to detect the requirement of strain $\mathrm{T} 9^{\mathrm{T}}$ for both vitamins and trace elements to utilize the hydrocarbons.

Without an added carbon source there was no growth of strain $\mathrm{T}^{\mathrm{T}}$ in $\mathrm{SWM}$. In addition to the growth with

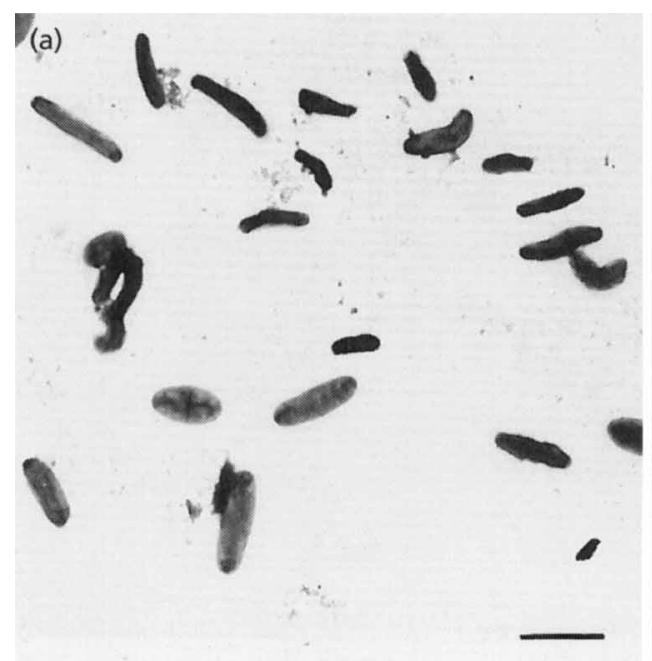

(b)

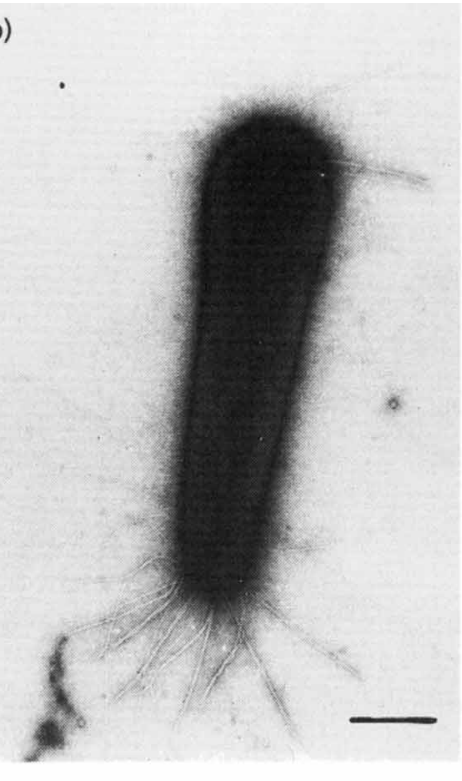

(c)

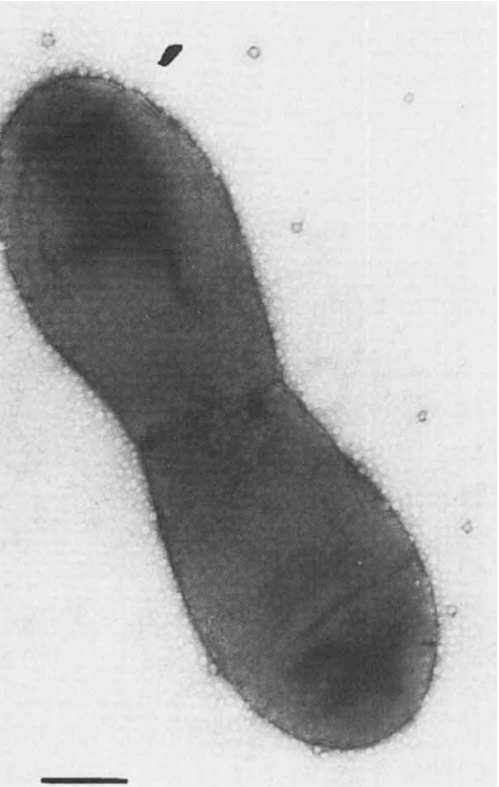

Fig. 1. Transmission electron micrographs of negatively stained strain $\mathrm{T} 9^{\top}$ cells grown at $25^{\circ} \mathrm{C}$ on modified nutrient agar. (a) A $42 \mathrm{~h}$ culture showing varying cell sizes; bar, $1.42 \mu \mathrm{m}$. (b) A cell from a $4 \mathrm{~d}$ culture showing pili; bar, $0.39 \mu \mathrm{m}$. (c) A $42 \mathrm{~h}$ culture showing binary cell division; bar, $0 \cdot 21 \mu \mathrm{m}$. 
Table 1. Phenotypic properties that differentiate $F$. jadensis from other related genera and species of Gram-negative bacteria

+ , Positive reaction or growth; $\mathrm{d}$, variable reaction; - , negative reaction or no growth; DR, different results; ND, no data available.

\begin{tabular}{|c|c|c|c|c|}
\hline Character & $\begin{array}{l}\text { Marinomonas } \\
\text { spp.* }\end{array}$ & $\underset{\text { Oceanospirillum }}{\text { Spp } \dagger}$ & $\begin{array}{c}\text { Marinobacter } \\
\text { hydrocarbono- } \\
\text { clasticus } \ddagger\end{array}$ & $\begin{array}{c}\text { Fundibacter } \\
\text { jadensis }\end{array}$ \\
\hline $\begin{array}{l}\text { Typical Gram-negative cell wall } \\
\text { profile }\end{array}$ & + & + & + & + \\
\hline Morphology & Rods & Helical cells & Rods & Rods \\
\hline No. and arrangement of flagella & 1 , polar & Bipolar tufts & 1 , polar, or none & None \\
\hline Optimal temp $\left({ }^{\circ} \mathrm{C}\right)$ & $20-25$ & $25-32$ & 32 & 30 \\
\hline Growth at $4{ }^{\circ} \mathrm{C}$ & - & DR & - & - \\
\hline Growth at $45^{\circ} \mathrm{C}$ & + & - & + & - \\
\hline Optimal $\mathrm{NaCl}$ concn $(\%)$ & $0 \cdot 7-3 \cdot 5$ & $0 \cdot 5-8$ & $3-6$ & 3 \\
\hline Maximal $\mathrm{NaCl}$ concn $(\%)$ & ND & $9 \cdot 75$ & 20 & 15 \\
\hline Nitrate reduced to nitrite & - & - & + & + \\
\hline Nitrite reduced to nitrogen & - & - & + & - \\
\hline Oxidase test & - & + & + & + \\
\hline Catalase reaction & ND & ND & + & + \\
\hline \multicolumn{5}{|l|}{ Utilization of: } \\
\hline D-Glucose & + & - & - & - \\
\hline D-Fructose & ND & - & - & - \\
\hline D-Mannose & + & - & - & - \\
\hline Sucrose & - & ND & - & - \\
\hline Cellobiose & DR & - & - & - \\
\hline D-Mannitol & + & - & - & - \\
\hline Glycerol & + & - & - & - \\
\hline D-Gluconate & + & $\mathrm{ND}$ & - & - \\
\hline Succinate & + & + & + & - \\
\hline L-Glutamate & + & DR & + & - \\
\hline Aspartate & ND & - & - & - \\
\hline DL-Alanine & + & $\mathrm{DR}$ & - & - \\
\hline L-Arginine & DR & - & - & - \\
\hline L-Serine & $\mathrm{DR}$ & - & + & - \\
\hline Pyruvate & ND & $\mathrm{d}$ & ND & + \\
\hline Acetate & ND & $\mathrm{d}$ & ND & + \\
\hline Tetradecane & ND & $\mathrm{ND}$ & + & + \\
\hline Hexadecane & + & ND & + & + \\
\hline Pristane & ND & $\mathrm{ND}$ & + & + \\
\hline Accumulation of PHB & - & + & - & + \\
\hline $\mathrm{G}+\mathrm{C}$ content $(\mathrm{mol} \%)$ & $44-48$ & $42-51$ & $52 \cdot 7$ & $63 \cdot 6$ \\
\hline
\end{tabular}

* Data from Baumann et al. (1984) and Gauthier \& Breittmayer (1992).

$\dagger$ Data from Krieg (1984).

$\ddagger$ Data from Gauthier et al. (1992).

different carbon sources, Table 1 summarizes the morphological and the nutritional profiles of strain $\mathrm{T} 9^{\mathrm{T}}$ and its nearest relatives. All strains listed need $\mathrm{NaCl}$ for growth. They were all motile with the exception of strain $\mathrm{T}^{\mathrm{T}}$. Comparing the four strains, only Marinomonas was able to use a variety of sugars as carbon sources. Oceanospirillum, Marinobacter as well as strain $\mathrm{T} 9^{\mathrm{T}}$ failed to use most of the carbon sources tested. Strain T9 ${ }^{\mathrm{T}}$ accumulated PHB as well as Oceanospirillum (Krieg, 1984).

\section{Fatty acid composition}

The analysed fatty acids of strain $\mathrm{T} 9^{\mathrm{T}}$ were as follows: $5.24 \%$ dodecanoic acid $\left(\mathrm{C}_{12: 0}\right), 1.06 \%$ 2-hydroxydodecanoic acid (2-OH $\left.\mathrm{C}_{12: 0}\right), 4.91 \%$ 3-hydroxydodecanoic acid $\left(3-\mathrm{OH} \mathrm{C}_{12: 0}\right), 1.73 \%$ tetradecanoic acid $\left(\mathrm{C}_{14: 0}\right), 0.23 \%$ 12-methyl-tetradecanoic acid (a$\left.\mathrm{C}_{15: 0}\right), 13 \cdot 50 \%$ cis $\Delta^{9}$-hexadecenoic acid $\left(\Delta^{9}-\mathrm{C}_{16: 1}\right)$, $23.40 \%$ hexadecanoic acid $\left(\mathrm{C}_{16: 0}\right), 20.70 \%$ cis $\Delta^{11}$ octadecenoic acid $\left(\Delta^{11}-\mathrm{C}_{18: 1}\right)$ and $29 \cdot 23 \%$ unidentified 
Table 2. Levels (\%) of $16 \mathrm{~S}$ rDNA sequence similarity between strain $\mathrm{Tg}^{\top}$ and related organisms

\begin{tabular}{|c|c|c|c|c|c|c|c|c|c|c|c|c|c|}
\hline Strain & 1 & 2 & 3 & 4 & 5 & 6 & 7 & 8 & 9 & 10 & 11 & 12 & 13 \\
\hline 1 Fundibacter jadensis strain $\mathrm{T}^{\mathrm{T}}$ & - & & & & & & & & & & & & \\
\hline $\begin{array}{l}2 \text { Marinobacter hydrocarbonoclasticus } \\
\text { ATCC } 49840^{\mathrm{T}}\end{array}$ & 88.9 & - & & & & & & & & & & & \\
\hline 3 Oceanospirillum beijerinckii ATCC $12754^{\mathrm{T}}$ & $88 \cdot 5$ & $89 \cdot 9$ & - & & & & & & & & & & \\
\hline 4 Oceanospirillum kriegii ATCC $27133^{\mathrm{T}}$ & $88 \cdot 5$ & $87 \cdot 3$ & $90 \cdot 4$ & - & & & & & & & & & \\
\hline 5 Marinomonas vaga ATCC $27119^{\mathrm{T}}$ & $88 \cdot 4$ & 87.9 & $89 \cdot 0$ & $90 \cdot 9$ & - & & & & & & & & \\
\hline $\begin{array}{l}6 \text { Oceanospirillum multiglobuliferum ATCC } \\
33336\end{array}$ & $87 \cdot 8$ & $88 \cdot 5$ & $95 \cdot 7$ & $90 \cdot 4$ & $89 \cdot 6$ & - & & & & & & & \\
\hline 7 Oceanospirillum maris ATCC 27649 & $87 \cdot 3$ & $88 \cdot 1$ & $95 \cdot 8$ & $89 \cdot 8$ & $89 \cdot 0$ & 95.6 & - & & & & & & \\
\hline 8 Oceanospirillum japonicum ATCC $19191^{\mathrm{T}}$ & $86 \cdot 7$ & $87 \cdot 9$ & $89 \cdot 6$ & $88 \cdot 1$ & $88 \cdot 8$ & $89 \cdot 0$ & $89 \cdot 7$ & - & & & & & \\
\hline 9 env. Agg53 & $86 \cdot 5$ & $86 \cdot 9$ & $86 \cdot 9$ & $87 \cdot 5$ & 88.4 & 87.5 & $86 \cdot 6$ & $85 \cdot 9$ & - & & & & \\
\hline 10 Piscirickettsia salmonis & $85 \cdot 0$ & $83 \cdot 5$ & $84 \cdot 7$ & 84.9 & $86 \cdot 3$ & $84 \cdot 9$ & 83.9 & $85 \cdot 0$ & $83 \cdot 5$ & - & & & \\
\hline 11 Thiomicrospira thyasirae DSM $5322^{\mathrm{T}}$ & $84 \cdot 5$ & $83 \cdot 0$ & $84 \cdot 3$ & $84 \cdot 9$ & $84 \cdot 7$ & $85 \cdot 2$ & $84 \cdot 5$ & $84 \cdot 0$ & $85 \cdot 0$ & $83 \cdot 9$ & - & & \\
\hline 12 Thiomicrospira crunogena ATCC $35932^{\mathrm{T}}$ & $83 \cdot 7$ & $82 \cdot 1$ & $82 \cdot 1$ & $84 \cdot 7$ & $86 \cdot 5$ & $83 \cdot 3$ & $82 \cdot 8$ & $83 \cdot 0$ & $84 \cdot 5$ & $85 \cdot 3$ & $91 \cdot 2$ & - & \\
\hline 13 env. SAR92 & $83 \cdot 6$ & $83 \cdot 6$ & $84 \cdot 9$ & $83 \cdot 7$ & $84 \cdot 0$ & $83 \cdot 8$ & $83 \cdot 4$ & $82 \cdot 7$ & $83 \cdot 0$ & $80 \cdot 4$ & $80 \cdot 4$ & $79 \cdot 5$ & - \\
\hline
\end{tabular}

fatty acids. Strain $\mathrm{T} 9^{\mathrm{T}}$ had a fatty acid profile which featured high proportions of palmitic $\left(\mathrm{C}_{16: 0}\right)$, palmitoleic $\left(\Delta^{9}-\mathrm{C}_{16: 1}\right)$ and cis-vaccenic $\left(\Delta^{11}-\mathrm{C}_{18: 1}\right)$ acid.

\section{Susceptibility to inhibitors}

Strain $\mathrm{T} 9^{\mathrm{T}}$ is sensitive to chloramphenicol, gentamicin and tobramycin. It is resistant to ampicillin, cefazolin, cephalotin, erythromycin, linomycin, nalidixic acid, novobiocin, ofloxacin, oxacillin, penicillin and tetracycline.

\section{DNA base composition}

The $\mathrm{G}+\mathrm{C}$ content of the DNA is $63.6 \mathrm{~mol} \%$, as determined by thermal denaturation.

\section{Phylogenetic analysis}

The almost complete 16S rDNA sequence of strain $\mathrm{T} 9^{\mathrm{T}}$ was determined by the DSMZ. Phylogenetic analysis of the $16 \mathrm{~S}$ rDNA demonstrated that this bacterium belongs to the class Proteobacteria, gamma subclass. This was confirmed by labelling the strain with a 23S rRNA-directed oligonucleotide probe (target position 1027-1043, 5' GCCTTCCCACATCGTTT 3').

Construction of a dendogram (Fig. 2) revealed that strain $\mathrm{T}^{\mathrm{T}}$ is most closely related to species of the Colwellia subclass of the gamma-Proteobacteria (Maidak et al., 1996). The greatest extent $(88.9 \%)$ of similarity exists between strain $\mathrm{T}^{\mathrm{T}}$ and Marinobacter hydrocarbonoclasticus. Calculating the relationship between strain $\mathrm{T} 9^{\mathrm{T}}$ and strains of the genera Marinobacter, Oceanospirillum, Marinomonas, Piscirickettsia and Thiomicrospira as well as between strain $\mathrm{T} 9^{\mathrm{T}}$ and the isolates env. agg53 (DeLong et al., 1993) and env. SAR92 (Britschgi \& Giovannoni, 1991) (Table 2) indicate that strain $\mathrm{T} 9^{\mathrm{T}}$ has no clear affiliation with any other bacteria of this phylogenetic group.

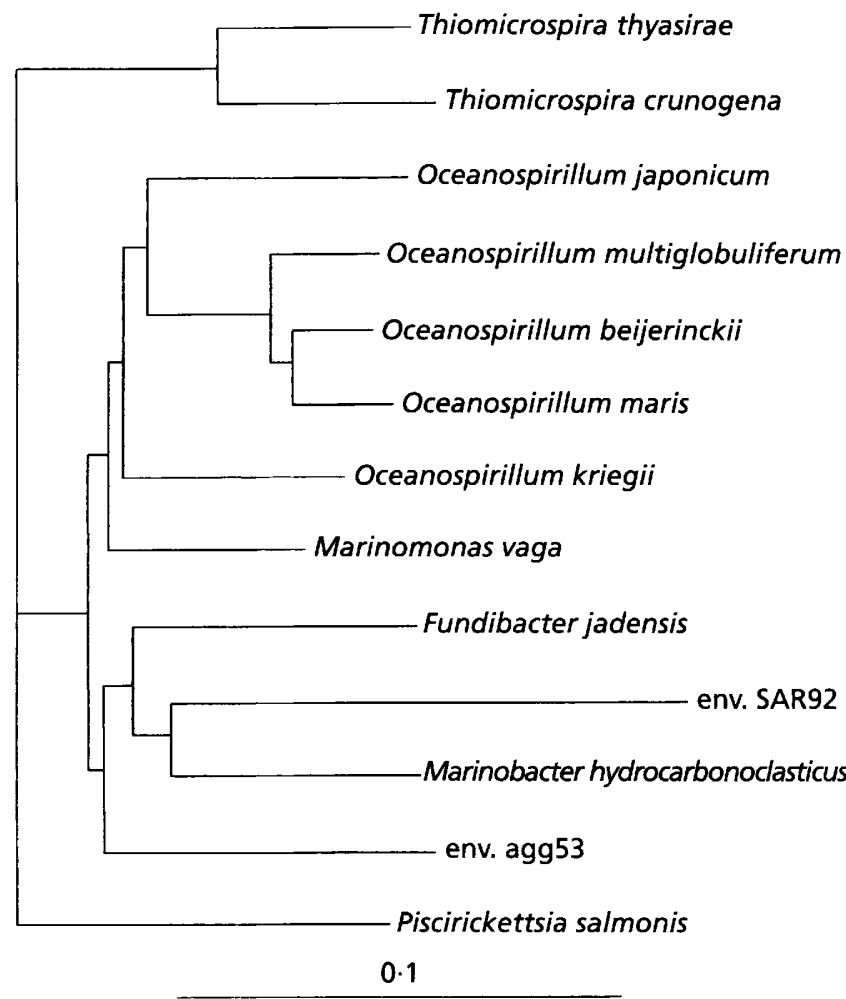

Fig. 2. Phylogenetic dendrogram based on the results of a $16 \mathrm{~S}$ rDNA sequence comparison. Comparative sequence data were obtained from the EMBL or RDP databases (Maidak et al., 1996). Bar, 10 nucleotide substitutions per 100 nucleotides.

\section{DISCUSSION}

Several methods to clarify the relation of $F$. jadensis strain $T 9^{\mathrm{T}}$ to other bacteria were used. In addition to phylogenetic analysis, we determined morphological and physiological characteristics. 
The morphology of $F$. jadensis is unusual because of the great variety in the size of the rods. This phenomenon was observed in young $(42 \mathrm{~h}$ ) and old (4d) cultures and in liquid as well as on solid media. One might think that strain $\mathrm{T} 9^{\mathrm{T}}$ belongs to the group of budding bacteria, where in some cases the daughter cells are smaller in diameter than the mother cells (Hirsch, 1974). However, as only a binary cell fission was observed, $F$. jadensis cannot be grouped along with the budding bacteria. The cause of the varying cell size of $F$. jadensis is unknown. Several other isolates obtained from mud-flat fermentations and also belonging to the gamma subclass of the Proteobacteria showed the same variability. In contrast to its nearest relatives Marinomonas, Oceanospirillum and Marinobacter, strain $\mathrm{T}^{\mathrm{T}}$ is not motile and has no flagella (Table 1). This may be explained by the habitat from which Fundibacter was isolated. In a sediment suspension, cells are often attached to particles. On account of such an immobilization, cell motility is not necessary. The Marinomonas, Oceanospirillum and Marinobacter species were originally isolated from seawater (Gauthier \& Breittmayer, 1992; Pot et al., 1992; Gauthier et al., 1992), whereas strain $\mathrm{T}^{\mathrm{T}}$ was isolated from a sediment suspension.

The fact that Marinobacter hydrocarbonoclasticus and strain $\mathrm{T}^{\mathrm{T}}$ are able to degrade long-chain hydrocarbons like hexadecane may be explained by the presence of hydrocarbons in the environments from which the strains were derived. Marinobacter hydrocarbonoclasticus was isolated from the Mediterranean Sea, near a petroleum refinery outlet, and strain $T 9^{T}$ from a continuous suspension culture containing intertidal sediment and hexadecane as the sole carbon source. As the mud flat region is rich in organic substances, one would expect strain $\mathrm{T}^{\mathrm{T}}$ to be an organism that metabolizes a wide range of carbon sources, including amino acids produced by the decomposition of organic material. Strain $\mathrm{T} 9^{\mathrm{T}}$ was able to metabolize peptone, which contains proteins, amino acids and vitamins, but it was not able to grow when amino acids were presented as the sole carbon source. On the basis of the 17 carbon sources tested (Table 1), we have to conclude that the nutritional profile of strain $\mathrm{T} 9^{\mathrm{T}}$ is even more restricted than that of the genera Marinobacter, Oceanospirillum and Marinomonas.

Marinobacter hydrocarbonoclasticus, the nearest relative of strain $\mathrm{T} 9^{\mathrm{T}}$, is a true denitrifier (Gauthier et al., 1992) whereas Marinomonas and Oceanospirillum fail to reduce nitrate at all. We therefore tested the denitrifying properties of strain $\mathrm{T} 9^{\mathrm{T}}$ and discovered that it is able to use nitrate as an electron acceptor under anaerobic conditions. However, strain $\mathrm{T}^{\mathrm{T}}$ is distinguishable from Marinobacter hydrocarbonoclasticus because of its capacity to reduce nitrate to nitrite without further reduction to nitrogen. The denitrifying capability of strain $\mathrm{T}^{\mathrm{T}}$ indicates a good adaptation of this organism to its environmental conditions. The intertidal mud flat zone of the North
Sea is characterized by cyclic variations in temperature and by a sharp drop from the aerobic to the anaerobic zone in the sediment within the space of a few centimetres. The temperature changes in summer occur cyclically with the tide between approx. $17^{\circ} \mathrm{C}$ in the water and $60^{\circ} \mathrm{C}$ when the flats dry and become exposed to the sun. This may explain why the temperature spectrum of strain $\mathrm{T} 9^{\mathrm{T}}$ reveals a mesophilic and not a psychrophilic oganism. The latter could have been expected if the bacteria had been isolated from the open sea.

The fatty acid composition of strain $\mathrm{T} 9^{\mathrm{T}}$ is characterized by high amounts of palmitic, palmitoleic and cis-vaccenic acid. $\mathrm{C}_{16: 0}, \mathrm{C}_{16: 1}$ and $\mathrm{C}_{18: 1}$ fatty acids were also described by Oliver \& Colwell (1973) as major fatty acids in the extractable lipids of several Gram-negative marine bacteria. Furthermore, the presence of hydroxy fatty acids is also interesting. The lack of hydroxy fatty acids in Spirillum linum (Oliver \& Colwell, 1973), formerly known as Oceanospirillum linum (Hylemon et al., 1973), and in a deep-sea isolate belonging to the genus Alteromonas (Wirsen et al., 1987) which is phenotypically closely related to Marinomonas, demonstrates that according to a chemotaxonomic marker like fatty acid profiles, strain $\mathrm{T} 9^{\mathrm{T}}$ is distinctly different from the genera Oceanospirillum and Alteromonas. According to Lechevalier (1977), the 3-OH $\mathrm{C}_{12: 0}$ fatty acid is a typical characteristic of Pseudomonas species. Yet the fatty acid profiles of several Pseudomonas species described by Moss et al. (1972) and by Oliver \& Colwell (1973) have a different composition from that of strain $\mathrm{T} 9^{\mathrm{T}}$. Thus, we conclude that the fatty acid profile of $F$. jadensis is unique, when compared to other phylogenetically related marine bacteria.

Another substantial feature of strain $\mathrm{T}^{\mathrm{T}}$ is its $\mathrm{G}+\mathrm{C}$ content, which is $63.6 \mathrm{~mol} \%$, and hence considerably higher than that of the phylogenetically related bacteria $(52.7 \mathrm{~mol} \%$ for Marinobacter, $4448 \mathrm{~mol} \%$ for Marinomonas and 42-51 mol \% for Oceanospirillum). This discounts the inclusion of strain $\mathrm{T} 9^{\mathrm{T}}$ in the genera Marinobacter, Oceanospirillum and Marinomonas. The $\mathrm{G}+\mathrm{C}$ content of strain $\mathrm{T} 9^{\mathrm{T}}$ is more closely related to that of the genera Pseudomonas (55-64 mol\%) and Alcaligenes (52-68 mol\%) (Gauthier \& Breittmayer, 1992) which also belong to the gamma subclass of the Proteobacteria. Moreover, Pseudomonas nautica belongs to the Colwellia-assemblage of the gammaProteobacteria (Maidak et al., 1996) as does strain $\mathrm{T} 9^{\mathrm{T}}$.

Binding of different rRNA-directed oligonucleotide probes indicated a clear affiliation of strain $\mathrm{T} 9^{\mathrm{T}}$ to the gamma subclass of the Proteobacteria. This was confirmed by the complete analysis of the 16S rDNA. The closest relatives for which 16S rDNA sequences are presently known are Marinobacter hydrocarbonoclasticus, $O$. beijerinckii, $O$. kriegii and Marinomonas vaga, but there is no clear affiliation to one single species. Since there is a significant distance in the $16 \mathrm{~S}$ rDNA sequence, and because of the great dissimilarity 
in the morphological and physiological traits of strain $\mathrm{T} 9^{\mathrm{T}}$ compared with other marine bacteria, we propose assigning it to a new species in a new genus, as Fundibacter jadensis gen. nov., sp. nov.

\section{Description of Fundibacter jadensis gen. nov., sp. nov.}

Fundibacter (Fun'di.bac.ter. L. masc. n. fundus the base, in this case the sea bed; M.L. n. bacter, masc. equivalent of Gr. neut. n. bakterion rod or staff; M.L. masc. n. Fundibacter rod of the base). Fundibacter jadensis (ja.den'sis. M.L. adj. referring to the region Jade which forms part of the bay 'Jadebusen', which belongs to the German North Sea coast).

The cells are rods with sizes varying between $0 \cdot 8$ and $1.8 \mu \mathrm{m}$ long and $0.3-0.7 \mu \mathrm{m}$ wide. Colonies are circular, $0.25-1.25 \mathrm{~mm}$ in diameter and ivory-pigmented. The cells are Gram-negative, non-motile and possess pili. The temperature spectrum ranges from 10 to $40^{\circ} \mathrm{C}$, with optimal growth occurring at $30^{\circ} \mathrm{C}$. Shows weak halotolerance and grows at $\mathrm{NaCl}$ concentrations ranging from $0 \cdot 5-15 \%(\mathrm{w} / \mathrm{v})$, optimally at $3 \%(\mathrm{w} / \mathrm{v})$. It is able to grow both aerobically and anaerobically, and reduces nitrate. It grows with the carbon sources pyruvate and acetate if SM is used and also with tetradecane, hexadecane and pristane, if the medium is supplemented with vitamins and mineral salts. The cells are resistant to ampicillin, cefazolin, cephalotin, erythromycin, linomycin, nalidixic acid, novobiocin, ofloxacin, oxacillin, penicillin and tetracycline. The $\mathrm{G}+\mathrm{C}$ content of the DNA is $63.6 \mathrm{~mol} \%$. According to the 16S rDNA sequence and the rRNA binding to rRNA-directed oligonucleotide probes, $F$. jadensis belongs to the gamma subclass of the Proteobacteria. The 16S rDNA sequence of strain $\mathrm{T}^{\mathrm{T}}$ has been deposited at EMBL as AJ001150. The type strain is strain $\mathrm{T}^{\mathrm{T}}\left(=\mathrm{DSM} 12178^{\mathrm{T}}\right)$.

\section{ACKNOWLEDGEMENTS}

We thank Professor Dr. P. Hirsch for his helpful discussion, S. Schröder for analysing the $\mathrm{G}+\mathrm{C}$ content and A. Schulte for her help in fatty acid analysis. The work was supported by the Umweltforschungszentrum Leipzig-Halle (UFZ).

\section{REFERENCES}

Baumann, P., Gauthier, M. J. \& Baumann, L. (1984). Genus Alteromonas Baumann, Baumann, Mandel and Allen 1972, $418^{\mathrm{AL}}$. In Bergey's Manual of Systematic Bacteriology, vol. 1, pp. 243-352. Edited by N. R. Krieg \& J. G. Holt. Baltimore: Williams \& Wilkins.

Berthe-Corti, L., Bruns, A. \& Hulsch, R. (1997). Semi-continuousflow cultures with marine sediment suspensions containing nonpolar carbon sources - culture control by a pneumatic sediment suspension dosage system. J Microbiol Methods 29, 129-137.

Britschgi, T. B. \& Giovannoni, S. J. (1991). Phylogenetic analysis of a natural marine bacterioplankton population by rRNA gene cloning and sequencing. Appl Environ Microbiol 57, 1707-1713.

Cole, R. M. \& Popkin, T. J. (1981). Electron microscopy. In
Manual of Methods for General Bacteriology, pp. 34-51. Edited by P. Gerhardt \& others. Washington, DC: American Society for Microbiology.

DeLong, E. F., Franks, D. G. \& Alldredge, A. L. (1993). Phylogenetic diversity of aggregate-attached vs free-living marine bacterial assemblages. Limnol Oceanogr 38, 924-934.

Drews, G. (1976). Mikrobiologisches Praktikum, 3rd edn. Berlin: Springer.

Gauthier, M. J. \& Breittmayer, V. A. (1992). The genera Alteromonas and Marinomonas. In The Prokaryotes, vol. 3, pp. 3046-3070. Edited by A. Balows \& others. New York: Springer.

Gauthier, M. J., Lafay, B., Christen, R., Fernandez, L., Acquaviva, M., Bonin, P. \& Bertrand, J. C. (1992). Marinobacter hydrocarbonoclasticus gen. nov., sp. nov., a new, extremely halotolerant, hydrocarbon-degrading marine bacterium. Int $J$ Syst Bacteriol 43, 568-576.

Grasshoff, K. (1983). Methods of Seawater Analysis. Weinheim: Verlag Chemie.

Hill, L. R. (1968). The determination of deoxyribonucleic acid base composition and its application to bacterial taxonomy. In Identification Methods for Microbiologists, Part B, pp. 177-186. Edited by B. M. Gibbs \& D. A. Snapton. New York: Academic Press.

Hirsch, P. (1974). Budding bacteria. Annu Rev Microbiol 28, 391-444.

Hylemon, P. B., Wells, J. S., Jr, Krieg, N. R. \& Jannasch, H. W. (1973). The genus Spirillum: a taxonomic study. Int $J$ Syst Bacteriol 23, 340-380.

Jukes, T. H. \& Cantor, C. R. (1969). Evolution of protein molecules. In Mammalian Protein Metabolism, vol 3, pp. 21-132. Edited by H. N. Munro. New York: Academic Press. Krieg, N. R. (1984). Genus Oceanospirillum Hylemon, Wells, Krieg and Jannasch 1973, 361 ${ }^{\mathrm{AL}}$. In Bergey's Manual of Systematic Bacteriology, vol. 1, pp. 104-110. Edited by N. R. Krieg \& J. G. Holt. Baltimore: Williams \& Wilkins.

Lechevalier, M. P. (1977). Lipids in bacterial taxonomy-a taxonomist's view. Crit Rev Microbiol 5, 109-210.

Levring, T. (1946). Some culture experiments with Ulva and artificial seawater. K Fysiogr Sallsk Lund Forh 16, 45-56.

Maidak, B. L., Olsen, G. J., Larsen, N., McCaughey, M. J. \& Woese, C. R. (1996). The ribosomal database project (RDP). Nucleic Acids Res 24, 82-85.

Mandel, M. \& Marmur, J. (1968). Use of ultraviolet absorbance temperature profile for determining the guanine plus cytosine content of DNA. Methods Enzymol 12, 195-206.

Moss, C. W., Samuels, S. B. \& Weaver, R. E. (1972). Cellular fatty acid composition of selected Pseudomonas species. Appl Microbiol 24, 596-598.

Näveke, R. \& Tepper, K.-P. (1979). Einführung in die mikrobiologischen Arbeitsmethoden. Stuttgart: Fischer Verlag.

Oliver, J. D. \& Colwell, R. R. (1973). Extractable lipids of gram negative marine bacteria: fatty-acid composition. Int $J$ Syst Bacteriol 23, 442-458.

Pot, B., Gillis, M. \& De Ley, J. (1992). The genus Oceanospirillum. In The Prokaryotes, vol. 3, pp. 2230-3236. Edited by A. Balows $\&$ others. New York: Springer.

Rainey, F. A., Ward-Rainey, N., Kroppenstedt, R. M. \& Stackebrandt, E. (1996). The genus Nocardiopsis represents a phylogenetically coherent taxon and a distinct actinomycete lineage: proposal of Nocardiopsaceae fam. nov. Int $J$ Syst Bacteriol 46, 1088-1092. 
Saitou, N. \& Nei, M. (1987). The neighbor-joining method: a new method for reconstructing phylogenetic trees. Mol Biol Evol 4, 406-425.

Sasser, M. (1990). Identification of bacteria by gas chromatography of cellular fatty acids. Newark, DE: MIDI.

Schlegel, H. G. (1992). Allgemeine Mikrobiologie, 7th edn. Weinheim: Georg Thieme Verlag.
Smibert, R. M. \& Krieg, N. R. (1994). General characterization. In Methods for General and Molecular Bacteriology, pp. 607-654. Edited by P. Gerhardt, R. G. E. Murray, W. A. Wood \& N. R. Krieg. Washington, DC: American Society for Microbiology.

Wirsen, C. O., Jannasch, H. W., Wakeham, S. G. \& Canuel, E. A. (1987). Membrane lipids of a psychrophilic and barophilic deepsea bacterium. Curr Microbiol 14, 319-322. 